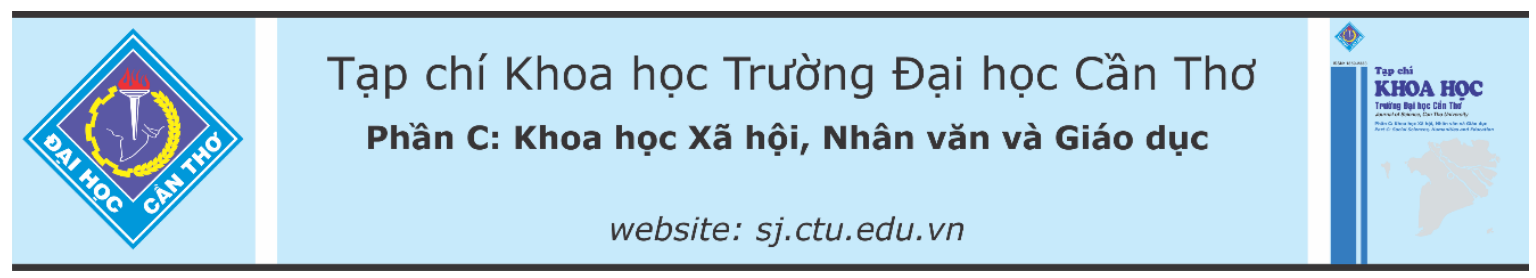

DOI:10.22144/ctu.jvn.2021.105

\title{
BÀN VỀ NGUỒN GỐC VÀ Ý NGHĨA CỦA ĐỊA DANH "CẦN THO"
}

\author{
Đào Ngọc Cảnh ${ }^{*}$ \\ Khoa Khoa học Xã hội và Nhân văn, Truò̀ng Đại học Cần Tho \\ *Nguoòi chịu trách nhiệm về bài viết: Đào Ngoc Cảnh (email: dncanh@ctu.edu.vn)
}

\section{Thông tin chung:}

Ngày nhận bài: $23 / 12 / 2020$

Ngày nhận bài sưa: 18/01/2021

Ngày duyệt đăng: 25/06/2021

Title:

About original sources and meaning of landmark "Can Tho"

\section{Tù khóa:}

Cần Tho, dịa danh, địa danh hoc, đồng bằng sông Cưu Long

\section{Keywords:}

Can Tho, landmark, Mekong Delta, toponymy

\begin{abstract}
Can Tho City, the center of the Mekong Delta region, play an important role in the region's socio-economic development. In the historical process, the land of Can Tho has had different names, including the name "Can Tho". This name was officially born in 1876 when the French protectorate established Can Tho county, then changed into Can Tho province. About the name "Can Tho", there are many studies mentioned. However, up to now, there are still different opinions. This article aims to exchange ideas to contribute to the clarification of the origin and meaning of the name "Can Tho" and some related names.
\end{abstract}

\section{TÓM TÁ̀T}

Thành phố Cần Tho là trung tâm vùng Đồng bằng sông Cửu Long, có vai trò quan trọng đối với sụ phát triển kinh tế-xã hội của vùng. Trong tiến trình lịch sứ, vùng đất Cần Tho có nhũng tên goi khác nhau, trong đó có tên gọi "Cần Tho". Tên gọi này chính thức ra đời năm 1876 khi chính quyền bảo hộ Pháp thành lập hạt Cần Tho; sau đổi thành tỉnh Cần Tho: Về tên goi "Cần Tho" đã có nhiều nghiên cứu đề cập đến. Tuy nhiên, đến nay vẫn còn nhũng ý kiến khác nhau. Bài viết này nhằm trao đổi ý kiến để góp phần làm sáng tỏ nguồn gốc, ý nghĩa tên gọi "Cần Tho" và một số tên gọi liên quan.

\section{GIỚI THIỆU}

Địa danh học là ngành khoa học nghiên cứu tên gọi các đối tượng địa lý tự nhiên và kinh tế-xã hội (KTXH) do con người đặt ra. Thông qua địa danh, người nghiên cứu có thể giải mã những vấn đề về sự hình thành và phát triển của một tộc người, một vùng đất, sự giao lưu và tiếp biến văn hóa của cộng đồng và nhiều thông tin về địa lý, lịch sử, văn hóa, du lịch gắn liền với địa danh đó.

Cần Thơ là thành phố trực thuộc Trung ương, đô thị loại I, trung tâm vùng Đồng bằng sông Cửu Long (ĐBSCL), đóng vai trò quan trọng đối với sự phát triển KTXH của vùng. Trong tiến trình lịch sử, vùng đất Cần Thơ có những tên gọi khác nhau, trong đó có tên gọi “Cần Thơ". Tên gọi này chính thức ra đời năm 1876 khi chính quyền bảo hộ Pháp thành lập hạt Cần Thơ, sau đổi thành tỉnh Cần Thơ (Tỉnh ủy \& UBND tỉnh Cần Tho, 2002).

Mặc dù địa danh “Cần Thơ" đã được nhiều tài liệu đề cập, nhưng đến nay vẫn còn những ý kiến khác nhau. Vì vậy, bài viết này nhằm trao đổi ý kiến để góp phần làm sáng tỏ nguồn gốc, ý nghĩa của địa danh "Cần Thơ" và một số tên gọi liên quan.

\section{DŨ̉ LIỆU VÀ PHƯƠNG PHÁP NGHIÊN CÚU}

\subsection{Dữ liệu nghiên cứu}

Nghiên cứu này chủ yếu dựa vào các bộ sách được biên soạn dưới triều Nguyễ்n như: (1) Gia Định thành thông chí do Trịnh Hoài Đức (1765-1825) 
biên soạn năm 1805 dưới triều vua Gia Long và dâng lên vua Minh Mạng vào năm 1820; sách này viết về 5 trấn thuộc thành Gia Định (nay là Nam Bộ) từ thời chúa Nguyễn đến hết thời Gia Long; (2) Đại Nam thưc lục do Quốc sử quán triều Nguyễn biên soạn trong 88 năm (1821-1909); sách này chép về các đời chúa Nguyễn và vua Nguyễn từ khi chúa Nguyễn Hoàng trấn thủ Thuận Hóa (1558) đến đời vua Khải Định (1925); đây được coi là bộ sử chính thống của triều Nguyễn, cũng là bộ sử đồ sộ bậc nhất của nước ta còn giữ lại đến ngày nay; (3) Quốc triều chính biên toát yếu do Quốc sử quán triều Nguyễn biên soạn dưới sự chủ biên của Tổng tài Cao Xuân Dục năm 1908; sách này tóm tắt những sự kiện chính từ sách Đại Nam thục lục để tiện cho việc sử dụng, nhất là phục vụ việc thi cử dưới triều Nguyễn; (4) Đại Nam nhất thống chí do Quốc sử quán triều Nguyễ̂n biên soạn vào thời Tự Đức (khoảng 18651882) và được xuất bản vào thời Duy Tân (1910); sách này được coi là bộ sách địa chí đầy đủ nhất dưới thời phong kiến Việt Nam.

Ngoài ra, nghiên cứu này còn sử dụng các nguồn tư liệu như: các công trình nghiên cứu, các dữ liệu dưới dạng văn bản, số liệu thống kê, bản đồ, hình ảnh, v.v...

\subsection{Phương pháp nghiên cứu}

\subsubsection{Phưong pháp địa lý hoc lịch sứ}

Địa lý học lịch sử là phương pháp nghiên cứu về sự thay đổi lãnh thổ địa lý qua các thời kỳ lịch sử. Phương pháp địa lý học lịch sử được vận dụng trong nghiên cứu này để tìm hiểu sự hình thành và biến đổi địa giới hành chính ở vùng đất Cần Thơ qua các thời kỳ lịch sử như đạo Trấn Giang, trấn Vĩnh Thanh, phủ Định Viễn, phủ Tuy Biên, huyện Vĩnh Định, huyện Phong Phú, hạt Cần Thơ, tỉnh Cần Tho,...

\subsubsection{Phuoong pháp tù nguyên học}

Từ nguyên học là phương pháp vận dụng ngôn ngữ học (từ vựng, ngữ âm, ngữ pháp) để truy tìm dạng từ ngữ nguyên gốc (từ nguyên) của địa danh. Trong nghiên cứu này, phương pháp từ nguyên học được vận dụng nhằm xác định từ nguyên của địa danh "Cần Thơ" dựa trên mối quan hệ với tên gọi dân gian (tục danh) của địa phương và sự chuyển hóa sang tiếng Việt theo phương ngữ Nam Bộ.

\subsubsection{Phuoong pháp tiếp cận liên ngành}

Tiếp cận liên ngành là phương pháp thích hợp và hiệu quả trong nghiên cứu địa danh. Vì vậy, nghiên cứu này tìm hiểu địa danh "Cần Thơ" theo phương pháp tiếp cận liên ngành từ nhiều góc độ: sử học, địa lý học, ngôn ngữ học và văn hóa học.

\section{NỘI DUNG NGHIÊN CÚU}

\subsection{Khái quát sự hình thành vùng đất Cần Tho}

Vùng đất Cần Thơ, cũng như toàn vùng Nam Bộ, xưa là lãnh thổ của vương quốc Phù Nam - một quốc gia cổ đại hình thành vào đầu Công Nguyên ở khu vực Đông Nam Á. Trong thời kỳ Phù Nam cường thịnh đã có nhiều nước nhỏ thần phục với tư cách là những thuộc quốc hoặc chư hầu, trong đó có nước Chân Lạp của người Khmer. Vào đầu thế kỷ VII, nhân lúc Phù Nam suy yếu, Chân Lạp đã tấn công và chiếm lấy (Phan Huy Lê, 2016; Vũ Minh Giang, 2019).

Dưới thời Chân Lạp, vùng đất này đã trở thành một vùng hoang hóa. Trong bối cảnh đó, nhiều cư dân Việt đã đến vùng này khai phá. Từ cuối thế kỷ XVI và đặc biệt là vào đầu thế kỷ XVII, người Việt từ đất Thuận Quảng đã đến vùng Mô Xoài, Đồng Nai (miền Đông Nam Bộ) khai khẩn đất hoang lập làng sinh sống (Vũ Minh Giang, 2019).

Trong tiến trình khẩn hoang Nam Bộ, vùng đất Cần Thơ được khai phá tương đối muộn. Cuối thế kỷ XVII, đầu thế kỷ XVIII, Mạc Cửu chiêu tập dân cư khai phá vùng đất Hà Tiên và dâng đất này cho chúa Nguyễn Phúc Chu để thuộc vào lãnh thổ Đàng Trong, thì vùng đất Cần Thơ vẫn còn là một vùng hoang hóa (Tỉnh ủy \& UBND tỉnh Cần Thơ, 2002; Trịnh Hoài Đức, 2006).

Năm Ât Mão (1735), Mạc Cửu qua đời, Mạc Thiên Tích nối nghiệp cha tổ chức khai phá mở mang thêm ở vùng hữu ngạn sông Hậu. Đến năm Kỷ Mùi (1739), công cuộc khai phá hoàn thành, Mạc Thiên Tích cho lập thành bốn đạo, đều thuộc trấn Hà Tiên. Đó là: đạo Long Xuyên (vùng Cà Mau), đạo Kiên Giang (vùng Rạch Giá), đạo Trấn Di (vùng bắc Bạc Liêu ${ }^{1}$ ), và đạo Trấn Giang (vùng Cần Thơ). Tại đạo Trấn Giang, Mạc Thiên Tích cho lập thủ sở bên bờ sông Hậu. Từ đó, thủ sở đạo Trấn Giang đóng vai trò hậu thuẫn cho Hà Tiên, được chú trọng phát triển trên mọi lĩnh vực quân sự, kinh tế-thương mại và văn hoá (Quốc sử quán triều Nguyễn, 1972; Trịnh Hoài Đức, 2006).

Do vị trí xung yếu nằm giữa Hà Tiên và Gia Định, trong thập niên 70 của thế kỷ XVIII, thủ sở đạo Trấn Giang trở thành cứ điểm quan trọng và

\footnotetext{
${ }^{1}$ Ngày nay là vùng Sóc Trăng
} 
phát triển mạnh trong bối cảnh lịch sử đầy xáo động. Tháng 3 năm Đinh Dậu (1777), quân Tây Sơn đánh chiếm Gia Định làm cho chúa Nguyễn Ánh phải chạy xuống Trấn Giang. Đến tháng 8 năm đó, quân Tây Sơn kéo xuống Trấn Giang, chúa Nguyễn cho quân đánh lại nhưng không được, phải lui. Đến năm Đinh Mùi (1787), quân Tây Sơn rút khỏi các dinh trấn ở miền Tây, vì thế Nguyễn Ánh mới thu lại được các vùng này. Năm Nhâm Tý (1792), Nguyễ் Huệ lâm bệnh qua đời, lực lượng Tây Sơn suy yếu và bị quân Nguyễn Ánh đánh bại. Năm Nhâm Tuất (1802), chúa Nguyễn Ánh lên làm vua với niên hiệu Gia Long. Năm Mậu Thìn (1808), vua Gia Long cho phân lập vùng đất mới từ Gia Định đến Hà Tiên thành 5 trấn: Phiên An, Biên Hòa, Định Tường, Vĩnh Thanh, Hà Tiên. Vùng đất Cần Thơ bấy giò thuộc trấn Vĩnh Thanh. Năm Quý Dậu (1814), huyện Vĩnh Định được thành lập, vùng đất Cần Tho thuộc huyện Vĩnh Định, phủ Định Viễn, trấn Vĩnh Thanh (Quốc sử quán triều Nguyễn, 2006).

Năm Nhâm Thìn (1832), vua Minh Mạng cho đổi "trấn" thành "tỉnh". Trấn Vĩnh Thanh được chia thành hai tỉnh là An Giang và Vĩnh Long. Huyện Vĩnh Định (trong đó có vùng đất Cần Thơ) được tách khỏi phủ Định Viễn, tỉnh Vĩnh Long để thuộc vào phủ Tân Thành, tỉnh An Giang. Đến năm Kỷ Hợi (1839), vùng đất Cần Thơ thuộc huyện Phong Phú, phủ Tuy Biên, tỉnh An Giang (Quốc sử quán triều Nguyễn, 2006).

Giữa thế kỷ XIX, thực dân Pháp đem quân xâm lược nước ta. Năm 1859, Pháp đánh chiểm thành Gia Định. Năm 1862, triều đình Nguyễn ký hòa ước nhượng ba tỉnh miền Đông Nam Kỳ cho Pháp. Đến năm 1867, thực dân Pháp đưa quân đánh chiếm ba tỉnh miền Tây Nam Kỳ. Sau đó, chính quyền thực dân Pháp lập ra một cấp hành chính dưới cấp tỉnh của triều Nguyễn, gọi là "hạt thanh tra" (inspections), dân gian quen gọi là "hạt". Tên các hạt thường không gọi theo tên Hán-Việt của triều Nguyễn mà gọi theo tục danh (cách gọi dân gian) của nơi đặt lỵ sở. Theo đó, tỉnh An Giang bao gồm ba hạt là: Châu Đốc (Tuy Biên), Sa Đéc (Tân Thành), Bãi Xàu (Ba Xuyên). Vùng đất Cần Thơ thuộc hạt Sa Đéc (Tỉnh ủy \& UBND tỉnh Cần Thơ, 2002; Dương Văn Triêm, 2019).

Năm 1871, Pháp cho đổi hạt thanh tra thành "hạt tham biện"2 (arrondissement). Nơi đặt trụ sở hạt tham biện gọi là tòa tham biện, dân gian quen gọi là

\footnotetext{
${ }^{2}$ Còn gọi là "tiểu khu" hoặc "tiểu khu hành chính"

${ }^{3}$ Chính phủ Việt Nam Cộng hòa
}

"tòa bố". Năm 1872, Pháp cho sáp nhập huyện Phong Phú với Bắc Tràng (thuộc phủ Lạc Hóa, tỉnh Vĩnh Long) để lập thành một hạt mới, đặt tòa bố tại Trà Ôn và chỉ một năm sau lại dời tòa bố về Cái Răng (Cần Thơ). Ngày 23/2/1876, Thống đốc Nam kỳ ra nghị định lấy huyện Phong Phú và một phần các huyện An Xuyên, Tân Thành để thành lập hạt Cần Thơ (arrondissement de Cantho). Năm 1899, Pháp ra nghị định đổi "hạt" thành "tỉnh"; "huyện" thành "quận"; việc chuyển đổi này được thực hiện vào đầu năm 1900. Theo đó, hạt Cần Thơ được đổi thành tỉnh Cần Thơ, gồm 4 quận: Châu Thành, Phụng Hiệp, Ô Môn, Cầu Kè. Năm 1921 có thêm quận Trà Ôn. Tỉnh lỵ tỉnh Cần Thơ đặt tại làng Tân An thuộc quận Châu Thành (Tỉnh ủy \& UBND tỉnh Cần Thơ, 2002).

Năm 1945, nước ta giành được độc lập, nhưng thực dân Pháp đã quay trở lại xâm lược; buộc nhân dân ta phải đứng lên chống Pháp. Trong thời kỳ chống Pháp (1946-1954), chính quyền kháng chiến có điều chỉnh một phần địa giới hành chính tỉnh Cần Thơ. Trong đó, Cần Thơ nhận thêm huyện Thốt Nốt (tỉnh Long Xuyên), các huyện Long Mỹ, Gò Quao, Giồng Riềng, thị xã Rạch Giá (tỉnh Rạch Giá) và huyện Kế Sách (tỉnh Sóc Trăng); đồng thời giao hai huyện Trà Ôn và Cầu Kè về tỉnh Vĩnh Trà (Vĩnh Long - Trà Vinh) (Tỉnh ủy \& UBND tỉnh Cần Thơ, 2002).

Năm 1954, sau Hiệp định Genève, ở miền Nam nước ta có hai hệ thống chính quyền song song tồn tại, thường gọi là chính quyền Sài Gòn ${ }^{3}$ và chính quyền Cách mạng ${ }^{4}$. Về phía chính quyền Sài Gòn: năm 1956, tên tỉnh Cần Thơ được đổi thành tỉnh Phong Dinh. Về phía chính quyền Cách mạng, tên gọi tỉnh Cần Thơ vẫn được duy trì nhưng địa giới hành chính có thay đổi một phần: Năm 1969, thị xã Cần Thơ được tách khỏi tỉnh Cần Thơ để trực thuộc khu Tây Nam Bộ. Năm 1971, thị xã Cần Thơ trở lại thuộc tỉnh Cần Thơ. Năm 1972, thị xã Cần Thơ trở thành thành phố Cần Thơ, trực thuộc khu Tây Nam Bộ (Tỉnh ủy \& UBND tỉnh Cần Thơ, 2002).

Sau ngày miền Nam giải phóng (30/4/1975), ta hủy bỏ hệ thống hành chính của chính quyền Sài Gòn, lấy lại tên gọi tỉnh Cần Thơ và thành phố Cần Thơ. Năm 1976, tỉnh Cần Thơ và thành phố Cần Thơ được hợp nhất với tỉnh Sóc Trăng thành tỉnh Hậu Giang. Đến cuối năm 1991, hai tỉnh Cần Thơ và Sóc

\footnotetext{
${ }^{4}$ Chính phủ Cách mạng lâm thời Cộng hòa miền Nam Việt Nam
} 
Trăng được tái lập trở lại (Tỉnh ủy \& UBND tỉnh Cần Thơ, 2002).

Ngày 26/11/2003, Quốc hội ra Nghị quyết chia tách tỉnh Cần Thơ thành thành phố Cần Thơ trực thuộc Trung ương và tỉnh Hậu Giang. Đầu năm 2004, thành phố Cần Thơ chính thức đi vào hoạt động với hệ thống hành chính mới bao gồm 4 quận: Ninh Kiều, Bình Thủy, Cái Răng, Ô Môn và 4 huyện: Phong Điền, Cờ Đỏ, Thốt Nốt, Vĩnh Thạnh (Quốc hội, 2003; Chính phủ, 2004).

Năm 2008, Chính phủ ra Nghị định điều chỉnh địa giới hành chính xã, thành lập xã thuộc huyện Thốt Nốt, Vĩnh Thạnh, Cờ Đỏ; thành lập mới quận Thốt Nốt và các phường trực thuộc; điều chỉnh địa giới hành chính huyện Cờ Đỏ để thành lập huyện Thới Lai thuộc thành phố Cần Thơ (Chính phủ, 2008).

Hiện nay, thành phố Cần Thơ có 9 đơn vị hành chính gồm 5 quận (Ninh Kiều, Cái Răng, Bình Thủy, Ố Môn, Thốt Nốt) và 4 huyện (Phong Điền, Cờ Đỏ, Thới Lai, Vĩnh Thạnh). Theo số liệu năm 2019, thành phố Cần Thơ có diện tích 1.439 km²; dân số 1.236 nghìn người; mật độ dân số 859 người $/ \mathrm{km}^{2}$ (Tổng cục Thống kê, 2020).

\subsection{Bàn về địa danh "Cần Tho"}

Theo ý kiến một số nhà nghiên cứu thì tên gọi "Cần Thơ" không được sử sách ghi chép rõ ràng. Sách Địa chí Cần Thơ (2002) có đoạn viêt: "Về tên goi Cần Tho, trong sủ sách xura nay, không có ghi chép xuất xú rõ ràng nhu tên gọi một số tỉnh khác, chỉ có nhũng truyền thuyết do các bô lão địa phuoong đời truớc kể cho con cháu đời sau" (Tỉnh ủy \& UBND tỉnh Cần Thơ, 2002).

Trong sách Cần Tho xua và nay, soạn giả Huỳnh Minh (1966) cũng cho rằng: "Riêng hai tiếng "Cần Tho"” trong sủ không có ghi chép rõ ràng nhu các tỉnh khác". Từ đó, ông đã đề cập đến nguồn gốc tên gọi "Cần Tho" do dân gian truyền lại như sau:

Thứ nhất: Tưong truyền lúc chúa Nguyễn Ánh trên đường bôn tẩu vào Nam đã đi qua nhiều noi để tránh Tây Sơn muru đồ phuc quốc. Lúc bấy giò Ngài ngự trên một chiếc thuyền đi ngang dòng sông Hậu, thuộc địa phận huyện Phong Phú thả thuyền theo sóng gió lênh đênh trên mặt nước, bỗng nghe tiếng ngâm tho, đàn địch, hò hát, hòa nhau rất nhịp nhàng. Ngài xúc động và đặt tên con sông này là Cầm Thi giang. Lần lần hai tiếng Cầm Thi được lan rộng ra dân chúng, được đọc trại là "Cần Tho" (Huỳnh Minh 1966, tr.49).
Thứ hai: Các bô lão địa phuoong kể lại rằng, noi đây xưa có trồng rất nhiều loại rau cần và rau thom, mỗi khi chủ vuờn cắt rau đem đi bán, rao cùng đưòng: ai mua rau cần, rau thom không?

Rau cần, rau thơm xanh mướt, Mua mau kẻo hết, chậm bước không còn.

Thiên ha xúm nhau mua hai loại rau này rất nhiều. Dần dần phổ biến thành câu ca dao:

Rau cần lại với rau thơm

Phải chăng đất ấy rau thơm có nhiều.

(Huỳnh Minh 1966, tr.50).

Có thể thấy rằng, hai cách giải thích này đều không có căn cứ rõ ràng và không thuyết phục. Bản thân soạn giả Huỳnh Minh cũng cho rằng: "Hai giả thuyết này không biết giả thuyết nào đúng" (Huỳnh Minh 1966, tr.50).

Giả thuyết thứ nhất có những điều bất hợp lý như sau: (1) về mặt tâm lý, chúa Nguyễn Ánh trong tâm trạng chạy trốn quân Tây Sơn thì không thể để tâm đến những người đàn hát trên sông mà đặt tên là "Cầm Thi”; (2) địa danh Hán-Việt thời bấy giờ được dùng rất phổ biến, nên nếu "Cầm Thi" là từ HánViệt, mà lại do chúa Nguyễn Ánh đặt, thì sẽ được dân chúng giữ nguyên, chứ không thể đọc trại thành "Cần Thơ".

Giả thuyết thứ hai cũng có những điểm bất hợp lý: (1) khi Trấn Giang còn là một thủ sở quân sự thì dân cư ở vùng này còn thưa thớt, thị trường chưa phát triển nên việc trồng nhiều rau để bán đến mức nổi tiếng là không thể xảy ra; (2) theo phương ngữ Nam Bộ, rau thơm được gọi là ngò (ngò rí, ngò gai,...), nên khi rao hàng phải gọi là "cần ngò"; (3) không có tài liệu hoặc bằng chứng thực tế nào cho thấy ở Cần Thơ xưa có nổi tiếng về trồng rau cần, rau thơm; (4) câu "ca dao" do soạn giả Huỳnh Minh dẫn ra "Phải chăng đất ấy rau thơm có nhiểu" là một câu hỏi tu từ, càng làm cho giả thuyết này thêm mơ hồ, khó chấp nhận.

Khi tra cứu các sử liệu về thời chúa Nguyễn và triều Nguyễn thì thấy tên gọi "Cần Thơ" đã có từ rất sớm, trước khi xuất hiện đạo Trấn Giang. Sách Gia Định thành thông chí do Trịnh Hoài Đức biên soạn dưới triều vua Gia Long vào năm Ât Sửu (1805) và dâng lên vua Minh Mạng vào năm Canh Thìn (1820) đã chép về "Cần Thơ giang" (sông Cần Thơ) như sau: "Cần Tho' giang: ở bò̀ phía tây Hậu Giang, rộng 8 tầm, sâu 5 tầm, cách trấn về phía nam 210 dặm ruõ̃i. Bên bờ phía tây là thủ sở đạo Trấn Giang, 
ở đây chợ phố đông đúc, buôn bán rất sầm uất..." (Trịnh Hoài Đức, 2006).

Cũng sách này khi chép về trị sở huyện Vĩnh Định đã nói đến "xứ Cần Thơ" như sau: "Huyện Vĩnh Định: Công việc khó khăn, trị sở tại đất thôn Tân An, xứ Cần Tho, quy chế như các huyện trước" (Trịnh Hoài Đức, 2006).

Đáng lưu ý, các sách chép về thời kỳ "bôn tẩu" của chúa Nguyễn Ánh đã nhiều lần đề cập đến địa danh Cần Tho . Sách Quốc triều chính biên toát yếu chép chuyện chúa Nguyễn Ánh đến Cần Thơ vào năm Bính Thân (1776) như sau: "Mùa đông năm Bính Thân, Ngài qua xứ Tam Phu (thuộc tỉnh Định Tuờng) chiêu tập binh Đông Sơn, Tây Son chiếm thành Sài Gòn (thuộc tỉnh Gia Định), đức Duệ Tôn vào Đăng Giang (thuộc tỉnh Định Tưòng), Ngài đem binh Đông Son ứng tiếp, hầu đức Duệ Tôn qua Cần Tho'..." (Quốc sử quán triều Nguyễn, 1972).

Sách Đại Nam thưc lục chép về sự kiện chúa Nguyễn Ánh hợp quân với Mạc Thiên Tứ (tức Mạc Thiên Tích) tại Cần Thơ vào năm Đinh Dậu (1777) như sau: "Mùa hạ, tháng 4, quân giặc đánh Tài Phụ. Chúa đi Long Hưng (tên đất thuộc tỉnh Định Tuờng). Gặp mura to, giặc đuổi không kịp. Đỗ Thanh Nhân tù Giá Khê dẫn quân lại. Chúa lại đi Cần Tho (tên đất, tức thủ sở đạo Trấn Giang, Mac Thiên Tú tù khi thất thủ Hà Tiên lui đóng ở đấy), hợp quân với Mạc Thiên Tứ" (Quốc sử quán triều Nguyễn, 2007).

Sách Quốc triều chính biên toát yếu chép về sự kiện quân Tây Sơn tấn công quân Nguyễn Ánh tại cửa Cần Thơ (nơi sông Cần Thơ đổ vào sông Hậu) vào năm Nhâm Dần (1782) như sau: "Tháng 3, Nhac, Huệ vào đánh cửa Cần Tho; Ngài sai Tống Phúc Thiêm đem binh thủy bày trận ở sông Thất Kỳy, giặc nhơn thắng thế xông tới, quân ta phải lui" (Quốc sử quán triều Nguyễn, 1972).

Dưới triều Nguyễn, thủ sở đạo Trấn Giang được sách Đại Nam nhất thống chí gọi là “thủ sở đạo Trấn Giang cũ” khi chép về sông Cần Thơ như sau: "Sông Cần Tho: ở về phía bờ tây Hậu Giang, cách huyện Phong Phú 3 dặm về phía đông, rộng 4 trượng, sâu 2 trượng rưỡi. Bờ phía tây là thủ sở đạo Trấn Giang cũ̃, phố xá trù mật, buôn bán tập nập” (Quốc sử quán triều Nguyễn, 2006).

Đồng thời, sách Đại Nam nhất thống chí còn chép về chợ Cần Thơ ở lỵ sở huyện Phong Phú như sau: "Cho Cần Tho: ở ly sở huyện Phong Phú, gần sông Cần Tho" (Quốc sử quán triều Nguyễn, 2006).
Như vậy, tên gọi "Cần Thơ" dùng để chỉ sông Cần Tho đã có trước khi chúa Nguyễn Ánh đến Trấn Giang. Đến thời chúa Nguyễn và triều Nguyễn thì ngoài tên sông, tên gọi "Cần Thơ" còn dùng để chỉ xú Cần Tho và chơ Cần Tho. Tuy nhiên, tên gọi "Cần Tho" lúc bấy giờ chỉ là địa danh dân gian, mà không được sử dụng làm địa danh hành chính. Đến thời Pháp thuộc thì tên gọi "Cần Thơ" mới được sử dụng cho đơn vị hành chính là hat Cần Tho.

Theo Dương Văn Triêm (2019), khi thiết lập các đơn vị hành chính ở Nam Kỳ, người Pháp rất lúng túng trước tình trạng các địa danh thường có 2 tên: mỹ danh (tên do triều đình đặt), tục danh (tên do dân gian đặt). Để chấm dứt tình trạng này, ngày 27/2/1868, Thống đốc Nam Kỳ De Lagrandière cho lập một ủy ban điều tra và chủ trương thống nhất sử dụng tên gọi dân gian (tục danh) cho các địa danh hành chính (Dương Văn Triêm, 2019, tr. 18).

Về nguồn gốc ngôn ngữ của tên gọi "Cần Thơ", nhiều nhà nghiên cứu cho rằng đó không phải là từ tiếng Việt hoặc Hán-Việt. Theo Bùi Đức Tịnh (1999), "Cần Tho không phải là tù Hán-Việt và không có nghĩa". Còn Lê Trung Hoa (2011) nhận xét: "Trong tiếng Việt hiện đại, Cần Tho không có ýnghĩa gi".

Từ những căn cứ như trên, có thể suy đoán rằng: tên gọi "Cần Thơ" bắt nguồn từ ngôn ngữ địa phương và được biến âm sang tiếng Việt (Việt hóa). Ở đây có thể nghĩ đến nguồn gốc tiếng Khmer, bởi vì người Khmer là một trong những cư dân bản địa ở Cần Thơ, cũng như ở ĐBSCL. Hiện nay, tại trung tâm thành phố Cần Thơ có hai ngôi chùa Khmer rất nổi tiếng là chùa Munir Ansay ở đại lộ Hòa Bình, phường Tân An và chùa Pitu Khosa Rangsay ở

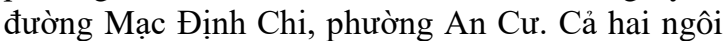
chùa này đều là những ngôi chùa Khmer hoành tráng và đẹp ở ĐBSCL. Đây là nơi sinh hoạt tôn giáo tín ngưỡng của người Khmer trong vùng và là điểm du lịch hấp dẫn đối với du khách khi đến thành phố Cần Tho.

Nói về người Khmer ở Cần Thơ, sách Chuyên khảo về tỉnh Cần Tho (Monographie de la province de Can-tho), xuất bản năm 1904, có đoạn viết : "Người Kho-me [nguoòi Khmer] truớc đây là nhũng nguời cu ngu duy nhất ở vùng này cho tới cuối thể kỷ qua, thời kỳ người An-nam [người Việt] bắt đầu tới định cu tai vùng đất này" (Hội Nghiên cứu Đông Dương, 2017, tr.47).

Về nguồn gốc tiếng Khmer của tên gọi "Cần Thơ", nhà nghiên cứu Bùi Đức Tịnh (1999) nhận xét: "...ngũu âm của tù Khmer Kìntho chỉ một loại 
cá hiện nay còn khá phổ biến ở Cần Tho, thông thuờng được goi là cá sặt rằn, nhưng đồng bào ở Ba Tri (tỉnh Bến Tre) vẫn gọi là cá lò tho. Tù quan điểm vũng chắc rằng lò tho là một danh tù chung tạo thành bằng cách Việt hóa tiếng Khmer Kìntho, nguoòi nghiên cúu có thể suu tầm nhũng tu liệu về lịch sư dân tộc, về sinh hoạt của người Khmer thời xa xua trong địa phuoong này trong nhiều huớng đi đến kết luận" (Bùi Đức Tịnh, 1999).

Còn nhà địa danh học Lê Trung Hoa (2011) cho rằng sự chuyển đổi từ Kìntho thành $C a \hat{a} n T h o$ là phù hợp với quy luật biến âm trong tiếng Việt: "Về mặt ngũ âm, âm cổ của vần "ân" là "in". OỎ thế kỷ XVII, người Việt nói: nhin đức (nhân đức), nhin sâm (nhân sâm), tiểu nhin (tiểu nhân),... Ngoài ra, giũa âm o (kin tho) và âm $\sigma^{\circ}$ (cần tho') cũng có nhiều tiền lệ chuyển đổi: (con) so - so (ban đầu), đó - nó (chố nó), (hàng) dỏm - rởm, hop (lại) - hơp,..." (Lê Trung Hoa, 2011).

\section{KẾT LUẬN}

Như vậy, từ các góc độ địa lý, lịch sử, văn hóa và ngôn ngữ, có thể hình dung quá trình hình thành và biến đổi địa danh "Cần Thơ" như sau: (1) tên gọi đầu tiên xuất hiện ở vùng này là sông $C a \hat{n} n T h o$, bắt nguồn từ tiếng Khmer "kìn-tho" (có nghĩa là cá sặc rằn); (2) từ tên sông Cần Thơ trở thành tên đất (xứ) Cần Tho và $c h o$ 'Cần Tho dưới thời chúa Nguyễn và triều Nguyễn; (3) đến thời Pháp thuộc, tên gọi "Cần Thơ" được đặt cho đơn vị hành chính là hạt Cần Tho"; (4) từ đó, tên gọi "Cần Thơ" được sử dụng làm địa danh hành chính các thời kỳ tiếp theo như tỉnh Cần Tho và thành phố Cần Tho đến ngày nay.

Nhìn lại lịch sử 265 năm từ đạo Trấn Giang (1739) và 128 năm từ hạt Cần Thơ (1876) đến thành phố Cần Thơ trực thuộc Trung ương (2004) thời gian thật là ngắn ngủi, nhưng Trấn Giang - Cần Thơ đã phát triển vượt bậc, từ một thủ sở quân sự trở thành một đô thị sầm uất, đóng vai trò quan trọng trong quá trình phát triển miền Tây Nam Bộ. Đáng lưu ý là sự phát triển của Cần Thơ không làm mất đi dáng vẻ hiền hòa, thơ mộng của một đô thị miền sông nước:

Cần Tho gạo trắng, nước trong

Ai đi đến đó, lòng không muốn về.

(Ca dao Nam Bộ)

\section{TÀI LIỆU THAM KHẢO}

Bùi Đức Tịnh. (1999). Luợc khảo nguồn gốc địa danh Nam Bộ. NXB Văn Nghệ, TP.Hồ Chí Minh.104 tr.
Chính phủ. (2004). Nghị định số 05/2004/NĐ-CP ngày 02/1/2004 về việc thành lập các quận Ninh Kiều, Bình Thủy, Cái Răng, Ô Môn, các huyện Phong Điè̀n, Cờ Đỏ, Vĩnh Thạn, Thốt Nốt và các xã, phường, thị trấn thuộc thành phố Cần Tho: https://thuvienphapluat.vn/van-ban/Bomay-hanh-chinh/Nghi-dinh-05-2004-ND-CPthanh-lap-cac-quan-Ninh-Kieu-Binh-Thu-CaiRang-O-Mon-huyen-Phong-Dien-Co-Do-VinhThach-Thot-Not-thuoc-thanh-pho-Can-Tho52394.aspx

Chính phủ. (2008). Nghị định số 12/NĐ-CP ngày 23/12/2008 về việc điều chỉnh địa giới hành chính xã, thành lập xã thuộc huyện Thốt Nốt, huyện Vĩnh Thạh, huyện Cờ Đö; thành lập quận Thốt Nốt và các phương trục thuộc; điều chinh địa giới hành chính huyện Cờ Đỏ để thành lập huyện Thới Lai thuộc thành phố Cần Tho: https://thuvienphapluat.vn/van-ban/Bo-mayhanh-chinh/Nghi-dinh-12-ND-CP-dieu-chinhdia-gioi-hanh-chinh-xa-thanh-lap-thuoc-huyenThot-Not-Vinh-Thanh-Co-Do-quan-Thoi-Laithanh-pho-Can-Tho-84050.aspx

Dương Văn Triêm. (2019). Địa giới hành chính Long Xuyên thời thuộc Pháp. Hội thảo khoa học "Lịch sủ 230 năm tù̀ thủ Đông Xuyên đến TP Long Xuyên", ngày 19/4/2019, An Giang, 17-26.

Hội Nghiên cứu Đông Dương. (2017). Chuyên khảo về tỉnh Cần Tho (Monographie de la province de Can-tho). NXB Trẻ, TP. Hồ Chí Minh. 51 tr.

Huỳnh Minh. (1966). Cần Tho xua và nay. Cánh Bằng xuất bản. Sài Gòn. 312 tr.

Lê Trung Hoa. (2011). Địa danh học Việt Nam, NXB Khoa học Xã hội, Hà Nội. 267 tr.

Phan Huy Lê. (2016). Vùng đất Nam Bộ quá trình hình thành và phát triển, tập 1 . NXB Chính trị Quốc gia - Sự Thật, Hà Nội, 757 tr.

Quốc hội. (2003). Nghị quyết số 22/2003/QH11 ngày 26/11/2003 về viẹc chia và điều chỉnh địa giới hành chính môt số tỉnh.

https://thuvienphapluat.vn/van-ban/Bo-mayhanh-chinh/Nghi-quyet-22-2003-QH11-chia-vadieu-chinh-dia-gioi-hanh-chinh-tinh-51694.aspx

Quốc sử quán triều Nguyễn. (1972). Quốc triều chính biên toát yếu, http://www.sugia.vn//assets/file/quoc-trieuchinh-bien-toat-yeu.pdf

Quốc Sử quán triều Nguyễn. (2006). Đại Nam nhất thống chí, tập 5. (Phạm Trọng Điềm biên dịch; Đào Duy Anh hiệu đính). NXB Thuận Hóa, Huế. 475 tr.

Quốc Sử quán triều Nguyễn. (2007). Đại Nam thục $l u c$, tập 1. (Nguyễn Ngọc Tỉnh biên dịch; Đào Duy Anh hiệu đính). NXB Giáo dục, Hà Nội. $1076 \mathrm{tr}$

Tỉnh ủy \& UBND tỉnh Cần Thơ. (2002). Địa chí Cần Tho: Cần Thơ. 935 tr. 
Tổng cục Thống kê. (2020). Số liệu thống kê năm 2019. https://www.gso.gov.vn/px-web$2 /$ ?pxid=V0201\&theme $=\mathrm{D} \% \mathrm{C} 3 \% \mathrm{~A} 2 \mathrm{n} \% 20 \mathrm{~s} \% \mathrm{E} 1$ $\%$ BB\%91\%20v\%C3\%A0\%201ao\%20\%C4\%91 $\% \mathrm{E} 1 \% \mathrm{BB} \% 99 \mathrm{ng}$

Trịnh Hoài Đức. (2006). Gia Định thành thông chí (Lý Việt Dũng dịch và chú giải; Huỳnh Văn Tới hiệu đính, giới thiệu), Tái bản lần thứ nhất. NXB Tổng hợp Đồng Nai. 1062 tr.

Vũ Minh Giang. (2019). Luoọc sử vùng đất Nam Bộ Việt Nam, NXB Đại học Quốc gia TP Hồ Chí Minh. 139 tr. 